\title{
V.O. Sukhomlynsky's Ideas About Reading as a Means for Development of a Child's Spiritual Needs Culture
}

\author{
Larysa Berezivska, Barbara Kalinowska-Witek
}

The article reveals the ideas of a prominent Ukrainian teacher, scientist, children's writer, director of Pavlysh secondary school V asyl Oleksandroyych Sukhomlynsky regarding reading as a means of forming a culture of a child's spiritual needs (to read, to study, to work, to defend the Motherland, etc.). The system of interconnected components of the process of forming the culture of pupils' spiritual needs (quality teaching of literature, extracurricular reading, literary and creative circles, etc.) developed by the teacher has been characterized. These ideas of a bumanist teacher are promising for further study and creative use in school practice.

Keywords: V.O. Sukhomlynsky, Ukrainian teacher, spiritual needs of a child, school, reading, book, library.

Nowadays, in the conditions of intensive development of the information society, complex social realities and political challenges, the need for finding effective means of forming a child's spiritual needs culture as the basis of the motivational sphere and the driving force of his or her development, is becoming more relevant. Reading has the priority among various means of forming a culture of a child's spiritual needs. This problem is extremely important all over the globalized world, for various states and educational systems. It acquires special relevance in Ukraine in line with the development of the New Ukrainian School as a strategic basis for educational reform. So, among the key competencies and pass-through skills which are the basis for the successful self-realization of a pupil as a person, citizen and specialist, the ability to read and understand what is being read is defined among the common skills for everyone (New Ukrainian School, 2016, p. 12). However, today, as it was noted by the academician, president of the National Academy of Pedagogical Sciences of Ukraine V.G. Kremen, «young people read little for the lack of time, but they are more connected to the Internet, a computer. ... Young people read, but not only the things 
which are recommended to them by curricula. Again, we should approach this taking into account the problem of new requirements and needs of an innovative person which time raises before him or her» (Kremen, 2009, p. 447). It is necessary to note that this problem was one of the key problems in the works of the outstanding Ukrainian humanist teacher, children's writer, director of the Pavlysh secondary school Vasyl Olexandrovych Sukhomlynsky (1918-1970). Celebrating the centenary of the teacher's birth in 2018, in accordance with the decision of the 39th session of the UNESCO General Conference, we were once again convinced of the relevance of V.O. Sukhomlynsky's creative heritage in Ukrainian and foreign educational space. Given this appeal to his ideas, it is advisable, since they are based on the results of the analysis of the teacher's multiyear work and, therefore, is a source of understanding the current issues of pedagogical theory and educational practice.

Ukrainian scientists (M.Ya. Antonets (2002), I.D. Bech (2013), N.A. Kalinichenko (2008), O.B. Petrenko (2011), O. Ya. Savchenko (2003), O.V. Sukhomlynska (2013), V.L. Fedyayeva (2006) and many others) and foreign scientists (E. Hartmann (2010) (Germany), A. Cockerill (1994) (Australia), Xiao Su (PRC), H. Frangos (1993) (Greece) and others)), trying to find previously unnoticed rational grains or to allocate the already known in the line of innovative changes in the educational field, continue to study Vasyl Olexandrovych's ideas on various pedagogical aspects (Antonets, 2002; Berezivska, 2018; Bech, 2013; Frangos, 1993; Kremen, 2009; Parcheta, 2001; Petrenko, 2011; Savchenko, 2003; Sukhomlynska, 2005, 2018).

Of course, today we are carefully re-reading the pedagogical works of the outstanding Ukrainian teacher V.O. Sukhomlynsky. So, he lived and worked in the Soviet times, when the Ukrainian Soviet Socialist Republic was a part of the Soviet Union. However, Vasyl Olexandrovych, ahead of the Soviet reality, was a humanist by his nature, so he tried to introduce universal human values into a totalitarian school. That is why with the declaration of Ukraine's independence in 1991, the revival of democratic and humanistic principles in education, the appeal to the teacher's ideas was intensified, and due to their multi-vector nature and child-centeredness they are becoming more relevant in the conditions of the New Ukrainian School development.

O. Sukhomlynsky's creative work has its supporters, who are more numerous than opponents. The best evaluation of the teacher's activities, in our opinion, is the considerations of his daughter, Doctor of pedagogical sciences, Professor, academician of the National Academy of Pedagogical Sciences of Ukraine O.V. Sukhomlynska: «... I am convinced that he is a creative, thinking teacher, moved from one shore to another, and he simply 
did not have enough time to come to the shore - after all, fate gave him only one decade - the 1960s» (Sukhomlynska, 2018, p. 16).

The purpose of our article is to reveal Vasyl Sukhomlynsky's ideas regarding reading as a means of forming a child's spiritual needs culture for their creative comprehension in the current conditions of the general secondary education reform.

For this, we have studied V.O. Sukhomlynsky's pedagogical works, in particular the books «A Schoolchild's Spiritual World», «How to Raise a Real Man», «Pavlysh Secondary School», «The Problems of Upbringing of a Comprehensively Developed Person», «A Conversation with a Young Director», «I am giving my heart to children«,» One hundred tips to the teacher», «Methods of educating the team», «Birth of a citizen «; articles «A Mighty Educaton», «Who is at the desk today?», etc. These and other teacher's works are stored in V.O. Sukhomlynsky State Scientific and Pedagogical Library of Ukraine of the National Academy of Pedagogical Sciences of Ukraine. Its web-portal (http://dnpb.gov.ua) represents the electronic information and bibliographic resource «Outstanding Educators of Ukraine and the World», an integral part of which is the "Sukhomlynsky Vasyl Olexandroyych» section, which presents the following information: the activist's biography; his works bibliography and materials about him; individual full-text works; photo gallery; societies, associations, institutions bearing the teacher's name; information about awards, prizes, monuments, pedagogical readings, online resources related to this outstanding figure, etc. Since 2003, library scholars have been directing research efforts to the development of Sykhomlynsky's studies, the popularization of the teacher's ideas in Ukraine and the world (Berezivska, 2018; Sukhomlynsky, 2018). The documentary fund of the reading room of the V.O. Sukhomlynsky's Foundation, which is a structural part of one and only Sykhomlynsky's studies sector in Ukraine of the V.O. Sukhomlynsky State Scientific and Pedagogical Library of Ukraine, has more than 5 thousand samples of documents, in particular, they include V.O. Sukhomlynsky's works in Ukrainian and more than 50 languages of the world; publications and materials devoted to the teacher on the scientist's use of the pedagogical heritage; publications (articles by V.O. Sukhomlynsky and about him) from periodicals, their copies (19761977), as well as documentaries about the teacher. The library staff prepared a complete and comprehensive bibliographic index «Vasyl Olexandrovych Sukhomlynsky: for the 100th anniversary of his birth», which presents publications from 1945 until 2017, dedicated to the teacher's life and his creative heritage, in order to popularize his heritage both in Ukraine and abroad. This publication is a key basis for a holistic historical and pedagogical study of V.O. Sukhomlynsky's ideas, his fictional work, as well 
as information about the research of the teacher's latest works by modern scientists (Berezivska, 2018).

The analysis of the teacher's works showed that among the priority tasks of the comprehensive development of the personality, Vasyl Olexandrovych determined the upbringing of his or her needs. Axiomatically sounds his opinion that «the active procurement of needs as the most important needs of the personality's spiritual values of is one of the most interesting problems of pedagogical theory and practice» (Sukhomlynsky, 1976 , p. 653). In this vein, the teacher raised the socio-pedagogical issues of the relationship of a person's material and spiritual needs, needs culture and desires culture upbringing. In particular, he wrote: «By upbringing highly moral, noble desires and refraining from desires that are unacceptable and forbidden, we thereby prevent great misfortune - derangement and depravity as a result of unbridled satisfaction of whims» (Sukhomlynsky, 1976 , p. 77).

The teacher expressed an outstanding idea about the harmony of interests, needs and desires of a particular pupil and the collective as a whole. It is achieved only when desires arise and are affirmed on the basis of bighly moral needs. The violation of the harmony between needs and desires causes devastation of the individual due to the absence of rich spiritual needs; the devastation of the collective, its transformation into the sphere of entertainment (Kalinichenko, 2008, p. 409; Sukhomlynsky, 1976, p. 16). That is why, according to Vasyl Olexandrovych, «all school life should be directed in such a way that a child from an early age could feel and understand the harshest border between the things which can be desired and the things which cannot be desired» (Sukhomlynsky, 1976a, p. 131). And finally, only the person who knows the limit of his or her desire can become a good citizen, a good friend (Sukhomlynsky, 1977 e, p. 289).

It is important that V.O. Sukhomlynsky interpreted the concept of a «need» as the «engine of human life», from which desires arise, which should be in harmony with the interests of the collective, society, people, the Motherland and should be cultivated from the first days of the child's conscious life. «The culture of human desires is the main road of family and school education», Vasyl Olexandrovych said (Sukhomlynsky, 1977 b p. 442).

The scientist attached an extremely great importance to the role of the teacher in the nurturing of the individual's ability to control one's own desires, on the basis of which spiritual needs are formed. He noted that at Pavlysh secondary school, teachers in conversations with pupils talked about «the internal discipline of desires as an integral feature of spiritual, moral culture» (Sukhomlynsky, 1976 , p. 603-604). The tutor's task is «to turn morally grounded and accepted for the society needs into a person's desires, internal motives» (Sukhomlynsky, 1976 f, p. 266). Still today relevant is 
V.O. Sukhomlynsky's advice to teachers: «Whatever subject you teach to adolescents or young people, you should awaken the craving for books inspired by the ideas which uplift and ennoble a person who is on the verge of independent life» (Sukhomlynsky, 1976 f, p. 361). The teacher personally wanted reading to become the most important children's spiritual need and he warned: "If a child does not have love of a book since childhood, if reading has not become its spiritual need for life, in the years of adolescence a teenager's soul will be empty ...» (Sukhomlynsky, $1977_{\text {h }}$, p. 201).

From this perspective, reflecting on such negative phenomena among adolescents and young people as drunkenness, hooliganism, thoughtless waste of time, Vasyl Olexandrovych prudently determined their reason - the limited intellectual interests in the school years. That is why he advised to work with a teenager, making the book captivating for him or her, «like a favourite tune, like a lovely dance«; and becoming a «new, incomprehensible miracle» (Parcheta, 2001, p. 422-423). In his opinion, «only the book will turn wonder into curiosity», «only reading opens the luxury of intellectual life to a person» (Sukhomlynsky, 2016, p. 509). V.O. Sukhomlynsky insisted that the teacher should know about teenager's intellectual interests, namely, «what place in his life is occupied by mental work, book and art.» The following thought sounds convincingly: «If a teenager lives only with movies, TV, a transistor receiver, tape recordings, if he does not know what reflections about his own fate are caused by a book, the reading of which is not an easy job, then no matter how much human fuss surround him, he is lonely» (Sukhomlynsky, 1977, p. 331). Vasyl Olexandrovych did not ignore the question of the teacher's need for reading and his or her own library "Reading is the source of the teacher's thought and creativity, it is life itself» (Sukhomlynsky, 1977 f, p. 254).

Vasyl Olexandrovych recommended teachers to have publications developing the knowledge of the program material in their personal libraries. In order to deepen elementary school knowledge, pupils under a teacher's guidance should read scientific or popular science books which contribute to the child's mental development (Sukhomlynsky, 1976, p. 474). He advised young teachers to buy literature monthly, in particular on the problems of the science taught by them; about the life and struggle of people who can be examples for young people; in psychology - «about a person's soul especially of a child, adolescent, a youth, a young girl.» Upon that, V.O. Sukhomlynsky gave various arguments: the teacher must constantly replenish scientific knowledge in order to see pupils' mental work, in addition, he is a «tutor, life teacher, mentor of children and youth,» who «must be an expert on the human soul which is being formed.» «Each book you read should somehow enter your workshop of education as a new 
delicate instrument», Vasyl Olexandrovych's appeal to young teachers of that time sounds relevant still today (Sukhomlynsky, 1976 e, p. 510).

V.O. Sukhomlynsky believed that a teacher's personal library should contain fiction for pupils: «Do not forget that the work of art read by your educatee and perceived by his or her inquiring mind and vulnerable heart can be the drop that the educator often lacks so that the scales are tilted in the direction you need» (Sukhomlynsky, 1976 e, p. 510). He advised teachers, when completing a personal library, to select the books which need to learn how to live for each pupil individually.

With his own example the teacher proved the importance of the library for professional growth, spiritual development, and a teacher's selfrealization. He wrote: «My personal library is my wise teachers, to whom I come daily to consult: where is the truth? How to recognize it? How to transfer from the older generations' soul and heart the moral wealth created, accumulated and received by humanity, into the younger generation's soul and heart? My books are my life teachers, to whom I turn daily with the question: how to live? How to be an example for my pupils? How to convey the light of ideal to their hearts?» (Sukhomlynsky, 1976, p. 509). Vasyl Olexandrovych had an abundant library where he selected publications only with significant artistic value. He wanted «this library to be the criterion of aesthetic culture.» Conversations with readers of the books from his library brought joy to the director, because they «expanded his pedagogical horizons» (Sukhomlynsky, 1977 g, p. 45-46).

Labour is the priority need of society and a powerful educational force in the culture of human desires. According to the teacher, desire culture nurturing was to take place namely through hard school work: «A person who has not learned how to manage his or her desires, who has not experienced their moral justification and validity, becomes socially unreliable, comes into conflict with social requirements». Reluctance to learn and unwillingness to work productively is one chain (Kalinichenko, 2008, p. 442-443). It is in the wealth of spiritual needs that lies the path to overcoming laziness. He stated: «... when already in childhood and especially in the years of adolescence, a person obtains such needs for his soul as the need for the joy of work, in a book, in communication with another person, in creation, in creativity, he or she receives the antidote from laziness» (Sukhomlynsky, 1976, p. 653).

V.O. Sukhomlynsky, having analysed the disappointing statistics (only 14 per cent of young people aged 20-35 spent time reading, the rest were engaged in various entertainments) and, finding out the causes of drunkenness, hooliganism and other negative phenomena that occurred among young people, he convinced of ponderability of reading as a means of forming a culture of free time spending. «Life convinces that when a 
young person has a nurtured passion for reading, in free time he or she will not be bored of idleness and look for cheap entertainment and pleasures,» the scientist wrote (Sukhomlynsky, 1977f p. 253). For this, schools should have reading rooms, book rooms, and for each pupil his or her own library should be created in the years of adolescence, which would be passed down from generation to generation and would be a family pride.

V.O. Sukhomlynsky convincingly substantiated the idea of the inseparability of school from book, obtained during the course of multiyear creative teaching work: "Only the attitude to the book as to the most important eternal and enduring spiritual value creates the attitude to school as to the people's cradle.» The teacher's reflections about extrusion of books as the leading means of upbringing by new sources coming to school, are still relevant (cinema, television, technical equipment). In his opinion, reading should become «the main person's spiritual need», and the school's extremely important task is «the ability to involve children in the world of books». «Reading a fictional work is the creativity of the mind and soul, and a child can perceive this creativity from the teachern, the teacher noted (Sukhomlynsky, 1977, p. 498).

In his opinion, reading should become «the most important person's spiritual need», and an extremely important task of school is «the ability to involve children into the world of books» (Kremen, 2009, p. 496). That is why the main holiday of Pavlysh secondary school was the Book Holiday, held at the beginning of school year. As Vasyl Olexandrovych described, on that day, parents bought their children a book for the family library. At the same time, selected books that were published over the past year were passed to the Eternal Library. Thus, books, like «the living and immortal roots of the people», became a continuous chain between generations (Sukhomlynsky, $1977_{a}$, p. 339-340). There were several Book Holidays of this kind during the year. In addition, the Ukrainian Word Room worked at the school, where Ukrainian writers' works were stored (Sukhomlynsky, $1977_{\text {b }}$ p. 498). Pupils came to school after lessons, during holidays, in order to read fictional works together with the teacher in the Fairy-Tale Room, Beauty Corner, Ukrainian Word Room.

As we see, V.O. Sukhomlynsky defined reading as the child's spiritual need which should be cherished by teachers first of all. Meanwhile, on the basis of his own observations, he raised the problem of reading as a significant means of forming the spiritual needs of pupils.

In the process of forming the needs and desires of a child, selfknowledge, self-education, self-improvement, to which the teacher devotes special conversations, play the leading role. He defended the idea of the interdependence of needs to exert physical and spiritual strength, overcome 
difficulties, gain joy in work and thus recognize himself: «A pupil can learn and educate himself only when the concept of work in his spiritual life is inextricably linked with the book» (Sukhomlynsky, 1976 , p. 603).

It is important that for this purpose at Pavlysh secondary school worked a system of ethical conversations with educates. Among the various topics of conversations on moral education (attitude to the sources of happiness and joy of childhood, adolescence and youth; obligation and duty to parents, older generations, the Motherland; the essence of the truth: Human as the highest value; veneration of the memory of the dead, etc.) and topics about the harmony of desires and responsibilities, desires and discipline, desires and present needs; about the ability to control the mind and be guided by the requirements of duty, and not just desires; about selfeducation of desires; about a worthy person and the like. It is positive that for this purpose there were compiled a manual of ethics for the educator and ethical readers for reading by pupils of different ages at school and in family (Sukhomlynska, 2013, p. 121). The Special Ethics Reader consisted of two thousand short stories and fairy tales, laid-out in five parts (for preschool children, for grades 1-2, 3-4, 5-7, 8-10), taking into account the age of children, their perceptions and interests. Another educational reader included moral values of mankind from ancient times to the present day. This very reader contained descriptions of the exploits in the name of the Motherland, the heroic struggle of peoples for freedom and independence, and the like. According to Vasyl Olexandrovych's description, reading the works in this reader, a young citizen «as if sees himself through the eyes of society, thoughtfully and demandingly analyses his actions, his behaviour» (Sukhomlynska, 2013, p. 123). He noted that the teaching staff sought that by means of reading «the pupils strive to make their life similar to the lives of those people as they see honour, dignity and personal pride in their work for people» (Savchenko, 2003, p. 152).

Of course, reading, the knowledge of literature and school education are closely related. According to V.O. Sukhomlynsky, individual reading as a creative process should be thoughtful, capture minds and arouse a sense of admiration for beauty, nobility, moral greatness or a sense of indignation, contempt, intransigence (Sukhomlynsky, 1976, p. 97]. He emphasised that by means of reading teaching staff should strive to encourage «the pupils to endeavour to make their life similar to the lives of those people as they see honour, dignity, personal pride in their work for people» (Sukhomlynsky, $1977_{g}$, p. 152].

In line with current socio-political events and scientific challenges, the teacher's fruitful ideas on the formation of schoolchildren's patriotic feelings and beliefs and the readiness of an educatee for a feat are becoming 
relevant. In «readiness to lay down his head for the Motherland,» Vasyl Olexandrovych saw «moral valour, without which the patriotic vision of the world today, patriotic worries and anxieties for the fate of the public, popular in his native city, village ...», which is the highest moral need (Sukhomlynsky, 1976 c, p. 133).

The teacher found that adolescents took interest in fictional works based on deep thought, especially in those places that «reflect a sense of spiritual community between people, fidelity, devotion,» referring to vigorous activity, in particular «about travel and unusual adventures of strong, brave and courageous people». «Scientific discoveries, heroic struggle for freedom and independence of the Motherland, the lives of historical figures, military leaders, scientists, inventors, production innovators - all this attracts adolescents,» the scientist noted, given the necessity to form in pupils the need to make scientific discoveries, heroic actions, to be like prominent people of various professions and so on. It is important for adolescents, when they read fictional works, to have a desire to write down in personal diaries their thoughts, views and beliefs about the things read, which shows an increase in their mental and emotional activity (Sukhomlynsky, 1976, p. 317-318).

V.O. Sukhomlynsky noted that reading works about the exploits of the Great Patriotic War heroes (especially of children and youth), about selflessness and fearlessness, about the fighters' self-sacrifice for the cause of the people, awakens exciting emotional and aesthetic experiences in adolescents. It is interesting that in children of primary school age, reading of literary works about the death of heroes caused «tears of pity and compassion,» and in adolescents - the awareness of the need for selfsacrifice for the benefit of society. Moreover, in his youth, according to the scientist, «the feeling of the heroic develops and deepens, occupying an increasingly prominent place in the moral world of man» (Sukhomlynsky, 1976 , p. 336).

That is why Vasyl Olexandrovych suggested selecting material for reading carefully, so that each book read could leave a deep mark in the child's heart and mind and help to discover new spiritual wealth for him or her. For this purpose, the creative team of Pavlysh secondary school, headed by V. O. Sukhomlynsky, developed and tested a number of effective forms which developed the need for reading: collective readings (multiple reading of favourite books in the Fairy-Tale Room, Ukrainian Word Room), lessons dedicated to reading schoolchildren's favourite; repeated reading of favourite poems with the aim of learning them by heart; evenings and mornings of expressive reading; Native Word Holiday; circles of lovers and venerators of the native word, where children and their parents took part; Book Holiday; 
children's, personal and family libraries, etc. (Sukhomlynsky, 1977 c, p. 498; Sukhomlynsky, $1977_{\text {i, p. }}$ 200-201).

A special place in the school library of Pavlysh secondary school was occupied by the Children's Library, which consisted of four departments. The first department was designed for four years of primary school. It contained stories of the greatest value for children's moral, mental and aesthetic education. Children read the works under the teacher's guidance both in the classroom and in extracurricular time. "This section of our library can be compared with a library of musical works intended for collective listening,» wrote Vasyl Olexandrovych (Sukhomlynsky, 2012, p. 333). The second section covered fairy-tales, poems, and fables for extracurricular reading at the child's choice. The third - ancient Greek mythology, which plays a big role in the intellectual and aesthetic education of children, "awakens the imagination, develops mind, fosters interest to the distant past» (Sukhomlynsky, 2012, p. 333-334). The children's library was the basis of teaching expressive reading, understanding the world, school of pupils' emotional and moral education.

At Pavlysh secondary school, a Golden Library of adolescence was created for teenagers in the Room of Thought, which included works of world literature. «We achieved the introduction of book into adolescents" spiritual life as the most important intellectual and aesthetic need,» Vasyl Olexandrovych stated proudly (Sukhomlynsky, 1977 e, p. 413]. It is important that the Golden Library as a «powerful educational force» included works that reflected «moral ideas - loyalty to the people, readiness to give their lives for their happiness, loyalty to beliefs, adamantness before the trials» (Sukhomlynsky, 1977 e p. 416). Based on his own observations, the scientist convincingly proved that «adolescents' self-education begins over a book and consists in measuring himself or herself by the highest measure courageous people' lives devoted to noble ideas» (Sukhomlynsky, 1977e p. 417). Vasyl Olexandrovych in his teaching work «strived to encourage a teenager to become engrossed in reading a book about an outstanding person's life and struggle, which embodied moral greatness and beauty» (Sukhomlynsky, 1977 e, p. 463).

Appealing to the Ukrainian writers of that time, Vasyl Olexandrovych convinced them to write works on exciting topics for teenagers and young people: ideological values, loyalty to beliefs, purpose of life, which would contribute to awakening patriotic feelings in children and youth (Sukhomlynsky, 1977 , p. 498).

Undoubtedly, reading as a powerful educational force affects an individual's needs. For example, the desire to learn, in V.O. Sukhomlynsky's opinion, becomes firmly established in a child only when his or her 
intellectual life passes among books, reading of which becomes the most attractive spiritual need for a schoolchild. The teacher substantiated the realization of this goal through extra-curricular reading: «Reading is an independent voyage into the sea of knowledge, and our task is to get for each pupil happiness from this voyage and feeling like a brave man who has come face to face with the boundless sea of human wisdom» (Sukhomlynsky, $1977_{\mathrm{a}}$, p. 431). As the scientist proved, reading should become the intellectual need of an individual, contribute to his or her desire to learn new knowledge (Bekh, 2013, p. 432).

At the same time, V.O. Sukhomlynsky constantly worried about the question why students reluctantly read good books, especially scientific ones. First of all, as the teacher reasoned, many teenagers do not know what real reading is: on the one hand it penetrates into the contents of the book and on the other - it «captures mind and heart, awakens thoughts about life, makes you think about your own future». In this sense, a teacher's important task was to help turn the book into a teenager's friend. The arguments given by the teacher are obvious: "If the book did not become a source of spiritual wealth, joy, pleasure for the student, many other spiritual needs are inaccessible; his world is poor, gloomy» (Sukhomlynsky, 1977 h, p. 480). The teacher was sure that «it is very important for a pupil to receive intellectual joy from reading,» in particular from reading magazines, popular science literature (Sukhomlynsky, 1977 g, p. 243). Such approach develops interest in books and science, which contributes to a better assimilation of knowledge in particular subject.

An effective means of forming the spiritual needs of adolescents at Pavlysh secondary school was the Room of Thought - a small reading room containing more than three hundred books. A special bookcase with special books stood in the room: about outstanding and courageous people's life. While reading, adolescents, capturing a person's name, had to turn it into an ideal «as the first impetus, an incentive to self-education.» According to V.O. Sukhomlynsky, books did not only open the world around the pupil, but also helped him to know and educate himself. And teachers should strive for this. It is also important to have in this room a bookcase with naturalscientific literature. Teachers, studying each pupil's interests, inclinations and abilities, offered him or her this or that books. Thus, they sought to turn the reading of a scientific book into a pupil's spiritual need (Sukhomlynsky, 1977 h, p. 481-483).

Vasyl Olexandrovych's reasoning about school's educational and upbringing task is currently becoming relevant - to help pupils to develop the need for reading and a sense of satisfaction with it. According to him, an effective form of realizing this task is a pupil's own (personal) library, which 
would be passed down from generation to generation, would become «family pride» (Sukhomlynsky, 1977f, p. 253). Pavlysh secondary school's teaching staff strove for each pupil to have a small library at primary school and a solid library of one hundred and fifty books at secondary and high school. Such libraries had to be filled with pupils' favourite editions so that they could re-read them. It was important for every, without an exception, pupil of Pavlysh secondary school to have his or her personal library (Sukhomlynsky, 1976 , p. 392). In line with the formation of spiritual needs culture, the teacher urged to take care of the «main, most important cultural centres - libraries» in general and of each pupil's personal library. He advised teachers to convince parents that «the personal library of their son and daughter is the greatest wealth», to nurture in pupils the need not only to read, but to re-read a good book too (Sukhomlynsky, 1977 h, p. 484).

The leading role in the formation of such libraries as well as love of books and reading, should be played by teacher: «To bring each pupil to the world of books, to cultivate love of books, to make book a guiding light in intellectual life - it depends on a teacher, on the place which a book occupies in his or her life» (Sukhomlynsky, 1976, p. 491). Vasyl Olexandrovych formed in his pupils love of book in the course of getting to know his own library. He wrote: «From the enthusiasm about my books, the desire to have one's own library is awakened in a child» (Sukhomlynsky, $1976_{b}$, p. 549). The teacher advised to develop in pupils the passion to collect books for creating their own libraries, and he encouraged teachers to have publications in the school or personal library, develop knowledge of program material among students. In order to deepen elementary school knowledge, pupils under a teacher's guidance should read scientific or popular science literature, which will contribute to a child's mental development (Sukhomlynsky, 1976, 474).

V.O. Sukhomlynsky's thought about the school library as a centre of a school's spiritual life, is relevant nowadays. He wrote that «here (in the library. - L. B.), many children's interests are satisfied, the light often lights up here awakening the dream» (Sukhomlynsky, 1977 , p. 65). It is important that several book lovers' circles worked at Pavlysh secondary school library of, where children read books, fixed and repaired them. The library circle kept a register of the books read with a list of pupils and books titles sorted vertically, which each pupil had to read. After reading the book, the pupil made a mark about it (Sukhomlynsky, 1977, p. 108). The collection «Immortal Works of the World Literature», which was obligatory for reading, was stored in a separate cabinets of the library. For high school pupils, scientific literature in the library was selected in different subjects. As Vasyl Olexandrovych reported, the problem with pupils who read few books 
from this list was discussed at the pedagogical council. The school library was a means of educational work, in particular with those pupils who, for various family reasons, were threatened by the emptiness of spiritual life (Sukhomlynsky, $1977_{g}$, p. 65). Vasyl Olexandrovych believed that the school library was to contribute to the organization of independent reading, which played a special role in a pupil's intellectual, moral and aesthetic development (Sukhomlynsky, 1977 a p. 431).

As you can see, V.O. Sukhomlynsky attached great importance to reading, in particular as a means of forming an individual's spiritual needs. It is important that a system of ethical conversations with pupils operated for this at Pavlysh secondary school. Among the various topics of conversations on moral education (attitude to the sources of happiness and joy of childhood, adolescence and youth; obligation and duty to parents, older generations, the Motherland; the essence of the truth: Man is the highest value; veneration of the memory of the dead, etc.). There were also topics about the harmony of desires and responsibilities, desires and discipline, desires and real needs; about the ability to control the mind and be guided by the requirements of duty, and not just desires; about self-education of desires; about a worthy person, etc.. It is positive that for this purpose there were compiled a Manual on ethics for the educator and ethical readers for reading by pupils of different ages in school and family (Sukhomlynsky, 1976 , p. 121). A special ethical reader consisted of two thousand stories and tales of an instructive nature, set out in five parts (for pre-schoolers, for 1-2, 3-4, 5-7, 8-10 grades), taking into account the children's age, their ideas and interests. Another educational reader included mankind's moral values from the most ancient time to the present day. Indeed it contained the descriptions of the exploits in the name of the Motherland, the heroic struggle of peoples for freedom and independence, and the like. Reading the works from the reader, as Vasyl Olexandrovych described, a young citizen «as if sees himself through the eyes of society, thoughtfully and demandingly analyses his actions, his behaviour» (Sukhomlynsky, 1976 c, p. 123).

The teacher wrote these stories and tales with deep educational content for children of preschool and primary school age. However, as the daughter of the prominent Ukrainian teacher, O.V. Sukhomlynska, notes, «Sukhomlynsky's recognition as a children's moralist writer came after his death» (Sukhomlynsky, 1977, p. 8). The fictional works by V.O. Sukhomlynsky as a children's writer are most fully represented in the collection «I will tell you a fairy tale ... Philosophy of childhood», structured and prepared for publication by O. V. Sukhomlynska (2016) (Sukhomlynsky, 1977). They entered the treasury of the Ukrainian and foreign school libraries and now are widely used in the educational process: they are 
included into textbooks and books for reading for pupils in grades 1-4 as well as into the Ukrainian schools' educational activities. They are read to children by parents, children read these works themselves.

Thus, V.O. Sukhomlynsky rightly considered the problem of school reading in two dimensions: as the spiritual need of children and youth, which needs to be cherished, and as a means of forming a culture of their spiritual needs. And these dominants, as it turned out, are inseparable. Based on the experience of Pavlysh secondary school, the teacher developed a system of interconnected logical and at the same time creative components of this process: high-quality teaching of literature, individual lessons in the artistic reading of a favourite work, extracurricular reading, literary and creative circles, Book Holiday, Fairy-Tale Room or Beauty Corner, the Ukrainian Word Room, Thought Room, pupils' personal libraries, an ethical reader, ethical conversations, careful selection of books for reading, and the like. Thoughtful reading of a book is not only an acquaintance with its content, but, first of all, self-knowledge and self-education, the foundation of a child's spiritual needs culture formation. And this is the human-creation essence of reading as a means of self-realization and self-creation of a person in various spheres of public life. The scientist defined the role of school, family and the public in nurturing spiritual needs culture of a child since the first days of his or her conscious life (to study, work, defend the Motherland, etc.), from which the desire arises, which should be in harmony not only with one's own, but also with public interests. These ideas of the outstanding Ukrainian humanist and educator are promising for further study, comprehension, and creative use in school practice.

\section{References}

Antonets, M. Ya. (2002). Native word in the didactic system of V.O. Sukhomlynsky. M.V. Levkivskyi (Ed.), National education: traditions and innovations in the context of Ivan Ogienko's ideas (pp. 193-198). Kyiv: Zhytomyr: ZhSPU.

Berezivska, L.D. (Ed.). (2018). Vasyl Oleksandrouych Sukhomlynsky: to the 100th anniversary of his birth: biobibliographic index. Vinnytsia: Works.

Bekh, I. (2013). The problem of the life-creation of the individual in the scientific research of V.O. Sukhomlynsky. Ridna Shkola, 8/9. 9-11.

Hartmann, E. (2010). V.O. Sukhomlynsky: a critic of the Soviet and capitalist systems. A New Look at the Legacy of Classics in Pedagogy. Shlyakh osvity, 1, 32-37.

Kalinichenko, N.A. (2008). Problems of upbringing of the patriot-citizen in pedagogy of Vasyl Sukhomlynsky and modern school. Pedagogical Bulletin, 3, $111-113$. 
Trends and Prospects of the Education System and Educators' Professional ...

Cockerill, A. L. (1994). V.O. Sukhomlynsky. Humanism in the Soviet school. (Phd thesis). School of Languages and Comparative Cultural Studies, University of Queensland, Brisbane.

Kremen, V. G. (2009). Philosophy of human-centrism in strategies of educational space. Kyiv: Pedagogical Thought.

New Ukrainian School: Conceptual Principles of Secondary School Reform. 10/27/2016 (2016). https://mon.gov.ua/storage/app/media/zagalna $\% 20$ serednya/novaukrainska-shkola-compressed.pdf

Parcheta, L. P. (2001). Expressive reading in the practice of V.O. Sukhomlynsky. Pedagogy and Psychology, 3/4, 233-237.

Petrenko, O. B. (2011). V. Sukhomlynsky and O. Zakharenko on girls' labor training: Gender aspect. V.O Sukhomlynsky Mykolayiv National University. Scientific Bulletin of V.O Sukbomlynsky Mykolayiv National University. Pedagogical Sciences Series, Vol. 1, Issue 35, (pp. 129-135). Mykolayiv: MNU.

Savchenko, O. Ya. (2003). Development of Sukhomlynsky's studies for ten years (1993-2003). Volodymyr Vynnychenko Kirovohrad State Pedagogical University. Scientific notes. Series: Pedagogical Sciences, Issue 52, Part 1, (pp. 18-22). Kirovohrad: V. Vynnychenko KSPU.

Sukhomlynska, O. (2013). Sukhombynsky's school in Pavlysh - a view through the lens of time. Kyiv: Pedagogical Thought.

Sukhomlynska, O. Artistic heritage of V. Sukhomlynsky in the cultural dimension. Ridna Shkola, 1, 3-7.

Sukhomlynska, O.V. (2005). Vasyl Sukhomlynsky. O.V. Sukhomlynska (Ed.), Ukrainian pedagogy in personalities: a textbook. for university students (Book 2: XX century, pp. 380-386). Kyiv: Lybid.

Sukhomlynska, O.V. (2018). Sukhomlynsky's creativity as an object of criticism: at that time and now. Volodymyr Vynnychenko Central Ukrainian State Pedagogical University. Scientific notes. Series: Pedagogical Sciences, Issue 171, (pp. 10-17). Kropyvnytsky: V. Vynnychenko TsDU.

Sukhomlynsky, V. O. (1977). Learning to learn. O.G. Dzeverin (Ed.), Selected works, Vol. 5, (pp. 426-436). Kyiv: Radyanska Shkola.

Sukhomlynsky, V.O. (1976). The spiritual world of a schoolchildren. O.G.

Dzeverin (Ed.), Selected works, Vol. 1, (pp. 299-400). Kyiv: Radyanska Shkola.

Sukhomlynsky, V.O. (1977). Letter to a young father. O.G. Dzeverin (Ed.), Selected works, Vol. 5, (pp. 440-446). Kyiv: Radyanska Shkola.

Sukhomlynsky, V.O. (1976). Methods of collective education. O.G. Dzeverin (Ed.), Selected works Vol. 1, (pp. 403-637). Kyiv: Radyanska Shkola.

Sukhomlynsky, V.O. (1977). The Mighty Educator. O.G. Dzeverin (Ed.), Selected works, Vol. 5, (pp. 495-499). Kyiv: Radyanska Shkola. 
Sukhomlynsky, V.O. (1977). Reward for good. O.G. Dzeverin (Ed.), Selected Works, Vol. 5, (pp. 288-292). Kyiv: Radyanska Shkola.

Sukhomlynsky, V.O. (1977). Birth of a citizen. O.G. Dzeverin (Ed.), Selected works, Vol. 3, (pp. 283-582). Kyiv: Radyanska Shkola.

Sukhomlynsky, V.O. (1977). People's teacher. O.G. Dzeverin (Ed.), Selected Works, Vol. 5, (pp. 239-254). Kyiv: Radyanska Shkola.

Sukhomlynsky, V.O. (1977). Pavlysh Secondary School. O.G. Dzeverin (Ed.), Selected works, Vol. 4, (pp. 7-390). Kyiv: Radyanska Shkola.

Sukhomlynsky, V.O. (1976). Problems of upbringing of a well-developed personality. O.G.Dzeverin (Ed.), Selected works. Vol. 1, (pp. 55-206). Kyiv: Radyanska Shkola.

Sukhomlynsky, V.O. (1977). Talking to a young director. O.G. Dzeverin (Ed.), Selected works, Vol. 4, (pp. 393-626). Kyiv: Radyanska Shkola.

Sukhomlynsky, V.O. (1977). I give my heart to the children. O.G. Dzeverin (Ed.), Selected works, Vol. 3, (pp. 7-279). Kyiv: Radyanska Shkola.

Sukhomlynsky, V.O. (2012). I give my heart to the children. Kharkiv: Acta.

Sukhomlynsky, V.O. (1976). One hundred tips for the teacher. O.G. Dzeverin (Ed.), Selected works, Vol. 2, (pp. 419-454). Kyiv: Radyanska Shkola.

Sukhomlynsky, V.O. (2016). I'll tell you a fairy tale ... A philosophy for children. Kharkiv: Shkola.

Sukhomlynsky, V.O. (1977). Who's at the desk today? O.G. Dzeverin (Ed.), Selected works, Vol. 5, (pp. 504-510). Kyiv: Radyanska Shkola.

Sukhomlynsky, V.O. (1976). How to educate a real person. O.G. Dzeverin (Ed.), Selected works, Vol. 2, (pp. 149-416). Kyiv: Radyanska Shkola.

Sukhomlynsky Vasyl Olexandrovych (2018). In V.O. Sukhomlynsky State Scientific and Pedagogical Library of Ukraine. http://dnpb.gov.ua/en/informationbibliographic-resources / outstanding-educators/Sukhomlynsky-v-o.

Fedyaeva, V.L., \& Sarayeva, O.V. (2006). V. Sukhomlynsky's pedagogical system: a study guide. Kherson: KSU.

Frangos, H. (1993). From Socrates to V. Sukhomlynsky through J. Piaget and L. Vygotskyi: Copernicus Coup in Education. Pochatkova Shkola, 10, 18-20.

Berezivska, L. D. (2018). Study of V. O. Sukhomlynsky's activity as a strategy of V. O. Sukhomlynsky State Scientific and Pedagogical Library of Ukraine. Education: Modern Discourses, 1, 208-214. 